\title{
Corruption And Foreign Direct Investment: What Have We Learned?
}

Leon Zurawicki, University of Massachusetts-Boston, USA Mohsin Habib, University of Massachusetts-Boston, USA

\begin{abstract}
Over 25 years of research pertaining to corruption and FDI rendered valid and interesting findings. We comment on these results to demonstrate that gradually the researchers develop a more detailed perspective on the significance of various dimensions of corruption and characteristics of the actors involved. Learning that corruption does not exert a uniform negative impact upon FDI, regardless of circumstances, leads to the formulation of the future research agenda.
\end{abstract}

Keywords: FDI, corruption, business environment, review.

\section{INTRODUCTION}

C orruption is an emotionally-laden term. Already by virtue of its etymology, corruption is a bad word and the literature starting at least with ancient Greek philosophers is replete with its condemnations. Over time, understanding of corruption has evolved. Until recently, most corruption-related material focused solely on the incidence of bribery. Some even argued that bribery could be beneficial to development. Now other types of corruption, more deleterious than bribery, are starting to be recognized, and their consequences for sustainable development ascertained. Also, private-public corruption now forays into private-private corruption.

Corruption, once broadly defined, can then be further broken down in many ways and into many categories. Corruption can be described according to where it occurs: at the political or bureaucratic levels of the public sector, or within the private sector. It can be defined according to its intensity: whether it is isolated or systematic. Other specifications include: grand versus petty, local versus national, personal versus institutional, and traditional versus modern.

The term 'corruption' is widely used in a rather loose manner in literature as well as in day-to-day context. There is no consensus on definition of corruption, either in literature or in practice. In recent years, concepts of corruption are broadly viewed from the perspectives of the western economies, although such economies themselves have not positively recognized the issue. Basically the concept has been derived from the ethical and moral perspectives and thus normative values are associated. Certain practices can always be viewed as corrupt under any situation, but there exist a wide range of borderline issues that can be debated. This makes identifying and dealing with corruption a significant challenge, both in the developed and developing economies.

\section{CORRUPTION INDICATORS AND THE IMPACT ON FDI-EARLY WORK}

It is around the late 1970s and early 1980s that some corruption indices started being published for a relatively limited number of countries. This spawned empirical and quantitative research on a variety of corruption related issues. Some of the key indices are as follows:

The first data set was created by Business International (BI) (1984), a subsidiary of The Economist Intelligence Unit. Data is available for the period 1980 to 1983 and covers nearly 70 countries. The data set measures "the degree to which business transactions involve corrupt payments" on a scale of 1 to 10 , as seen by BI's network of correspondents. Before this, corruption indices could have been derived from the Institutional Quality 
indices but these were not widely available. Using Institutional Quality indices as a surrogate measure for corruption is based on the long held argument since Adam Smith that market friendly institutions support economic development.

World Competitiveness Report is a business publication produced by the World Economic Forum in Switzerland. It consists of a survey of top and middle managers in the most dynamic firms of a large number of countries. The study reports, among other things, a measure of corruption for the countries. Political Risk Services (PRS) Group also started reporting in the mid-1980s corruption data. Since 1989, the surveys have asked a corruption-related question about "the degree to which improper practices (like corruption) prevail in the public sphere."

Armed with the new gauges, in the early 1990s the researchers in international business turned their attention to corruption and FDI. Hines (1995) found that after controlling for growth of host countries' gross domestic product (GDP) corruption negatively affected growth of U.S.-controlled FDI during 1977-82. This result is consistent with the theoretical arguments proposed by researchers.

Rose-Ackerman (1999), for example, argues that paying bribes is, in a way, akin to paying blackmail. Although payment of a bribe may help a firm win a contract, it also exposes the firm to future extortion attempts, especially when bribes are paid to obtain investment opportunities. Once a company has made a substantial capital investment, the cost of refusing to pay a bribe (say for a final permit to operate) increases.

Following theoretical arguments pointing to the damage corruption inflicts on the economy, several studies looked at the impact of corruption on the inflows of foreign direct investment. Della Porta and Vanucci (1999) corroborated the assumption that corruption is a detriment to FDI and hence a liability to the host economy.

One has to be cautious, though, about the results from the numerous studies on corruption. Availability of different corruption (and related) indicators based upon different methodologies adds to some confusion and can have some impact on the results of studies undertaken ${ }^{1}$. For example, in one study of the Canadian outgoing FDI over 15 years, the "Rule of Law" was hardly significant except for one specification model (Beaulieu, E., S. Chen and E. Pohjola, 2005).

\section{CORRUPTION'S EFFECT ON FDI}

Based upon general economic studies showing the adverse impact of corruption on economic growth, productivity and investment (Myrdal 1968, Mauro 1995), it follows that the logic would generally apply to foreign investors as well. The more so, if the latter are not used to corruption in their respective countries. It has been argued that given a choice between a familiar country (with less corruption) and a less familiar country, firms will gravitate toward the more familiar one (Davidson, 1980). The impact of corruption per se on international business had not emerged as a separate topic for empirical studies until the early 1990s. Earlier, corruption was implicitly lumped together with other factors in the composite index of political stability.

The first studies attempted then to isolate and estimate the overall impact of corruption on FDI. Typically, the format applied to such analysis was based upon the gravity models in which corruption as an independent variable was used along with the control variables such as the GDP of the host country and its growth rate, the GDP/capita, tax and exchange rates, labor market conditions (wages, unemployment), the degree of internationalization of the recipient economy, distance from the global markets, and political risk. Some variations also included other factors such as availability of the natural resources, the historical ties (metropolis-former colony), technological development and others. It is important to emphasize that the scope of the initial studies was constrained due to the data limitations. First databases pertaining to corruption covered no more than 40 countries and, what is more, were static in nature. The data did not permit any longitudinal analysis. Since the number of observations available was limited, the number of variables to be included in the econometric models also had to be

\footnotetext{
${ }^{1}$ For a recent critique refer to Kaufmann, D. and A. Kraay (2008), Governance Indicators: Where Are We, Where Should We Be Going?, The World Bank Research Observer Advance Access published online on January 31, 2008 ,
} 
small so as not to violate the statistical rules. Interestingly, the first results did not confirm the expected relationship. The often quoted study by Wheeler and Mody (1992) of US firms did not find a significant negative relationship between the size of foreign investment and the risk factor of the host country, a composite measure which beyond twelve other indicators also includes corruption. A later study by Hines (1995) showed an overall insignificant effect of corruption on incoming FDI. However, at the same time this work pointed to a negative impact of corruption on the FDI originating from the US after 1977. This result was attributed to the effectiveness of the US Foreign Corrupt Practice Act (FCPA). Thus, it was not the corruption per se which acted as a detriment to the US outgoing FDI but rather a perspective of being (severely) punished if caught by home country authorities. This distinction is still important today as it hints to why corruption is a deterrent. One plausible explanation would be that it is not (only) the corruption per se which acts as an impediment but the risk of being punished if the briber is exposed.

Subsequent analyses used more extensive data-since 1995 the Corruption Perception Indices have been compiled by Transparency International and gradually each year covered the ever increasing number of countriesand examined not only the aggregate FDI flows to the recipient countries but the bilateral FDI flows as well. In particular, two studies by Wei (1997a, 1997b) analyzing bilateral flows from 14 home- to 45 host-countries demonstrated that perceived corruption has a negative effect on incoming FDI comparable to additional tax levied on investors. He suggested that severe corruption has a similar effect to increasing the host country tax rate by an additional 40-50\%. Further, in comparing groups of host and home countries he found that corruption does not have a smaller effect on FDI into East Asian host countries. In addition, the American investors tend to be no more averse to corruption in host countries than (on the average) investors from other OECD countries with possibly exception of Japan. Wei (1997b) also introduced an interesting idea about the uncertainty surrounding the mechanisms of corruption - negotiating the terms and securing the commitments' delivery in the shady deals. Unfortunately, since this analysis was based on unpublished individual survey responses the analysis could hardly be replicated.

Recently, Gani (2007) investigated the relationship between indicators of governance and foreign direct investment (FDI) using a sample of countries from Asia and Latin America. While controlling for standard FDI variables, the results provide strong confirmation that the rule of law, control of corruption, regulatory quality, government effectiveness, and political stability are positively correlated with FDI.

Sanyal and Samanta (2008) examined US Foreign Direct Investment (FDI) outflows with respect to the level of corruption -- in the form of bribery -- in 42 recipient countries over a five-year period. Analysis indicates that US firms are less likely to invest in countries where bribery, as measured by the Corruption Perceptions Index (CPI), is widespread. However, the size of the foreign market is found to be a more robust factor determining US outward investment, with larger economies attracting more investment. The level of bribery, while significant by itself, loses its importance when included with other economic and cultural variables. The findings are discussed in the context of the Foreign Corrupt Practices Act (FCPA), which makes it illegal for US firms to bribe foreign officials to obtain business advantages.

It is important to emphasize that valuable inputs into understanding the impact of corruption were gradually produced not only by academics but also through the studies sponsored by business consulting companies. One of them-Control Risks-sponsored a 1999 survey which specifically asked a very pointed and differently phrased question: did you hold back from an otherwise attractive foreign investment on account of a country's reputation for corruption? A positive answer was provided by roughly the same percentage of the European and US companies and averaged $39 \% .^{2}$

By the late 1990s, additional analyses helped to detail the overall understanding of the impact of corruption on the FDI, while some other studies focused on more specific aspects. As for the first issue, the new studies attempted to estimate the evil of corruption with respect to FDI. In that respect, the quantitative models demonstrated to what extent corruption is a detriment to FDI relative to other factors.

\footnotetext{
${ }^{2}$ The percentage has not changed much since then. See Control Risks 2007, International Business Attitudes to Corruption Survey 2006, http://www.control-risks.com/pdf/corruption_survey_2006_V3.pdf.
} 
Regarding the second stream of thought, it focused on the impact of corruption in specific contexts: geographic regions, industries, host-home country relations, types of FDI (for example, market-seeking vs. efficiency-seeking). Some studies looked also into the implications of corruption for the form of investment (for example, wholly own subsidiaries vs. joint-venture).

In the following, we shall comment on the work published during the last 10 years as per the topics researched. As it is clear that many of the issues have not been resolved yet, this approach will help to highlight the avenues for future research.

\section{CORRUPTION RELATIVE TO OTHER HURDLES TO FDI}

In a series of studies, the general perception of the harmfulness of corruption and related phenomena received additional support. For example, Drabek and Payne (1999) tested the effect of non-transparency on foreign investors. The notion of non-transparency combined corruption, unstable economic policies, weak and poorly enforced property rights, and inefficient government institutions that increase the risk and uncertainty associated with business. The corresponding scale was adopted from the International Country Risk Guide published by the US-based Political Risk Services (PRS). Results showed that high levels of non-transparency decreased the flow of foreign investment to the host country.

Further, corruption was shown to be detrimental in a number of ways and linked to other institutional phenomenon. For example, market entry has been shown to deteriorate with high levels of corruption. Djankov et al. (2002) juxtaposed the data on the regulation of entry of start-up firms in 85 countries with the accompanying corruption and existence of unofficial economies. Countries with heavier regulation of entry have higher corruption and larger unofficial economies. While not specifically concerned with the international enterprises, the results of the study in question prove certainly of relevance to FDI.

Using data on foreign and local direct investments in 111 countries over a five-year period (1994-98), Habib and Zurawicki (2001) demonstrated the negative impact of corruption on foreign compared to local direct investments. Interestingly, local direct investment seems to be substantially (on the average 2 times) less affected than foreign direct investment. Furthermore, the influence of corruption appears to be weakened by such factors as the degree of international openness of the host market and the political stability of the country. Similarly, Lambsdorff (2003) showed that the overall capital inflows of a country decrease with corruption.

One should note that already early studies distinguished among different contexts which accounted for the impact of corruption. An original approach by Busse et al. (1996) examined the relationship between FDI and investors' perception of corruption resulting from the media exposure of corrupt practices. This study proposed that regardless of the scope of the reports, FDI would increase when investors believed that the government would institute reforms to curb corruption. By the same token, FDI showed a tendency to decrease with media exposure when investors felt that the government was unwilling or unable to change the environment for better. Consequently, they argued that the government's action will ultimately create a positive perception for foreign investors.

It is interesting, though, that the business cost of corruption does not need to be prohibitive and consequently moderates its effect on FDI. Kaufmann (1997) reported surveys in Ukraine and Russia (both perceived quite corrupt according to Transparency International) on the amount of illegal payment made for various business activities. His results suggest that the payments, on average, amounted to a small percent of total sales. If this is true of most situations then corruption may not be a major deterrent for FDI.

Showing the evil of corruption in relative terms (for example, compared to taxing profits) has been a useful method to show the role of various factors affecting FDI. This approach was pioneered by the World Bank since 1997. Such assessments represent the natural outcomes of the models applied and variables used. At the same time, those illustrations point to possible trade-offs in that a country's bad corruption record can be offset by ratings on other dimensions. One of the interesting examples was provided by Asediu (2008) who documented that with respect to African countries a decline in the corruption from the level of Nigeria to that of South Africa has the same positive effect on FDI as increasing the share of fuels and minerals in total exports by about 35 per cent. 
Finally, it is relevant to mention that corruption in conjunction with other negative phenomena can actually produce disproportionate negative effects as suggested by Zhao et al. (2003) who looked at the combined effect of high corruption and low transparency.

\section{IMPACT OF VARIOUS ELEMENTS OF CORRUPTION}

Over time, partly in response to richer data available the researchers started pursuing new interests based upon the distinctions in the newly developed characterizations of corruption. Note that Wei (1997b) was among the first to draw attention to the distinction between the "organized" and "chaotic" corruption (compare also Campos et al., 1999, on predictability of corruption and investment). This avenue has been pursued by other researchers. For example, Lambsdorff (2003) confirmed that opportunism, alongside with levels of corruption, reduces a country's annual capital inflows. In the same spirit Rodriguez et al. (2005) developed two parallel measures of corruption: pervasiveness and arbitrariness, the latter reflecting its volatility ${ }^{3}$. Drawing on that methodology, Cuervo-Cazurra (2008) analyzed the FDI flows into just one subgroup of the transition economies: the former Soviet Bloc countries and compared the specificity of this group with the larger sample of national economies of the world. The results prove odd in that the arbitrariness of corruption appears to be somewhat positively associated with the FDI into the transition economies, whereas this is not the case for the general sample. Since the lack of predictability would in theory increase the business uncertainty and volatility, the above paradox even if only limited to one group of countries requires a scrutiny and further studies.

Kaufmann and Wei (1999) showed that high levels of corruption are positively associated with the amount of time the managers waste with bureaucrats suggesting that it is the mundane everyday variety which is a nuisance. This issue appears particularly relevant in the context of the so called petty corruption. The distinction between the grand and petty corruption is potentially of interest even if, as in the opinion of a number of authors (see Ades and DiTella, 1996), the two are not unrelated. Interestingly, Lambsdorff and Teksoz (2005) claim that it is petty corruption that deters international investors more than the grand "political" one. They used a repertory of scales quoted in the 2003 Global Competitiveness Report of the World Economic Forum which may be collapsed into 2 respective types of corruption. Their conclusion (and explanation) was that grand corruption in government policy making and in judicial decisions less deters investors because they might feel belonging to an inner circle of insiders that can profit from hidden arrangements. Grand corruption also entails relatively smaller organizational effort. Straub's (2008) refinement on the same subject hints, however, that after reaching a certain threshold value the impact of petty bureaucratic corruption upon FDI gets weakened substantially.

\section{IMPACT OF CORRUPTION ON FDI COMPARED TO OTHER FORMS OF INTERNATIONAL BUSINESS}

It is rather amazing how little quantitative research has been devoted to the issue of corruption affecting exports. An earlier publication by Lambsdorff (1998) hardly fills the gap. Habib and Zurawicki (2005) compared the coefficients for analogous regressions to contrast the impact of corruption on FDI with the impact on trade. Incidentally, theirs was the first study considering the impact of corruption in the home country upon its outgoing FDI. Negative effects of corruption on import, export, FDI inflow, and FDI outflow are found. Further, it shows that the impact of corruption is higher in case of FDI inflow than with respect to exports to a country. Also, the impact of corruption is higher for FDI outflow than import from a country. Consequently, contrasting the impact of corruption on trade with the analogous influence upon FDI sheds new light on the substitutability between various forms of international business as a result of corruption.

\section{DOES CORRUPTION AFFECT DIFFERENT PARTIES DIFFERENTLY?}

Many published studies tried to average the assessment of the impact of corruption on FDI across the possibly large number of national economies in order to uncover a common pattern. As we have noted above, these analyses generated support for the overall negative effect of corruption on FDI. However, no attention was paid to

\footnotetext{
${ }^{3}$ To an extent, we would like to stress that arbitrariness has not only to do with the parties' respect for their commitments but also with the uncertainty regarding a possibility of being caught in the midst of the corrupt deal.
} 
the possibility that the adverse relationship might indeed reveal a varying pattern at different corruption levels. Such a proposition was made and supported by Caetano and Caleiro (2006) who adopted the "fuzzy logic" approach in order to determine conceivable clusters in the FDI-corruption space for 97 countries. Such a methodology revealed the existence of two separate clusters: one formed by high-level corruption countries for which corruption is negatively correlated with FDI, and the other consisting of low-level corruption countries, where the influence of corruption on FDI is far less obvious. The implication of this result is in line with the intuition and seems to confirm that there might exist a (presumably high) threshold of acceptable corruption such as that any further improvements exert a relatively minor impact on the growth of FDI. Such a dichotomy suggests that, for practical reasons, far more attention needs to be devoted to the corruption-FDI connection in the countries with poor corruption record. With respect to such economies even a small improvement in perceived corruption can have a dramatic positive impact on inflow of FDI. An interesting corollary to these finding can be found in the article by Winner and Egger (2006) who noted that corruption is an important impediment of FDI in developed economies but not in less developed ones. Taken into consideration that corruption is typically more rampant in the less developed countries, the contradictory nature of the two studies become rather obvious.

Foreign versus local investors has been considered an important distinction for understanding the effect of corruption. As noted earlier, Habib and Zurawicki (2001) observed that corruption exerts a stronger negative impact upon FDI relative to domestic investment in the host country. This would suggest that, all other things being equal, faced with corruption local investors are in a more advantageous position presumably in view of their experience with the domestic markets and specific know-how in operating in the unethical environment. With respect to a similar variable - institutional efficiency - this view was later supported by Aizenman and Spiegel (2006). That, however, need not be universally true. Following his econometric analysis, Lambsdorff (2003) proposed that multinational firms might substitute lacking bureaucratic quality for the quality of political connections. In the same spirit, Huang (2005) pointed out that the regulatory advantages of foreign firms vis a vis at least some local companies appear stronger in corrupt countries than in non-corrupt countries.

Is it possible that exposure to corruption in the home market conditions the potential investors to better handle corruption in the target markets? Habib and Zurawicki (2002) looked at the absolute differences in perceived corruption level between the investors' home and host countries as one of the independent variables and found that indeed similarity in overall corruption positively affects the bilateral FDI flows. This implies that FDI originating from and geared to more corrupt economies are less inhibited than analogous FDI flowing from less corrupt countries. Potentially, this "birds of feather flock together" syndrome produces a specific pattern in the geographic distribution of FDI and might explain why in general FDI rather fail to help improve corrupt markets.

This line of thought was further pursued in the analysis by Cuervo-Cazurra (2006) who showed that corruption results in a change in the composition of the countries of origin of FDI. He showed that corruption results in relatively lower FDI from countries that have signed the OECD Convention on Combating Bribery. Second, corruption results in relatively higher FDI from countries with high levels of corruption. Presented differently, analogous argument was made by Kotov (2008) who looked at the changes in business environment, including corruption, in various parts of the world from 1998 through 2005 to find that German investors are reluctant to get involved in the BRIC (Brazil, Russia, India and China) countries despite the positive publicity they have received.

An interesting contribution by Hakkala et al. (2008) has recently drawn attention to the possibility that corruption may differently interact with the established FDI projects depending on whether they are export- or local market-oriented. Based upon a study of Swedish multinationals, these authors concluded that the affiliates' sales within the host country market suffered as a result of corruption. What is surprising, however, is that the increase in the local corruption (for those Swedish subsidiaries) went hand in hand with the increased export sales. Unless it is just the mirror reflection of the first observation by the authors, such an unexpected finding calls for an elaborate theoretical explanation.

\section{CORRUPTION AFFECTING THE TYPE OF OWNERSHIP AND THE MODE OF ENTRY}

In terms of managerial implications foreign investors can either choose to stay away from corrupt environments or adapt accordingly. Apart from delegating the responsibility for bribery etc. to independent agents 
(Bray, 2005), foreign investors can benefit from various forms of partnerships with local businesses more expert in handling corruption (Habib and Zurawicki, 2001). This is a double-edged sword as in corrupt environment the integrity of business partners can be put in question.

Wei and Smarzynska (2000) focused on the impact of corruption in a host country on foreign investors' choice between a joint venture and a wholly owned subsidiary. Note that their empirical analysis of the firm level data was restricted to the former Soviet bloc economies. In doing so, they found support for the hypothesis that corruption shifts the ownership structure towards joint ventures. However, the importance of protecting intangible assets increases with investor's technological sophistication, which tilts the preference away from joint ventures in a corrupt country. As an exception, US investors were found to be more averse to joint ventures in corrupt countries than investors of other nationalities. Whether this should be ascribed to the implementability of the Foreign Corrupt Practices Act remains yet to be demonstrated.

Another relevant article in the same field by Uhlenbruck et al. (2006) focused specifically on the telecommunications industry in 64 emerging economies. Their analysis shows that corruption in the telecom markets shifts the preference of foreign businesses away from the wholly owned investment projects towards joint ventures and further to non-equity forms of operation. In addition, given a fixed level of corruption in a country, the stronger arbitrariness dimension only accentuates the tendency.

\section{FUTURE AVENUES}

As the yearly data from Transparency International (CPI scores) show, corruption is not disappearing any time soon (see also, Kaufman 2004) and bureaucracy will continue to provide significant avenues for corruption. While studies have shown some of the key effects of corruption, future researchers may have to consider other, possibly new, areas of corruption with regard to FDI. Identifying the sources is important but so is the solution. Attempts ought to be directed at the different possibilities for managing this problem, if not entirely eradicating it. In particular, much attention has been paid to static analyses relating the current level of corruption to current investment decisions. In view of the long-term horizon for most of the FDI projects, it is rather expectations regarding the evolution of corruption in the future which are potentially of interest to the investors. Pending availability of such forecasts, an important refinement can be added to our state of knowledge.

Extant literature hints at differential effects of corruption on FDI. One promising venue in this regard is examining the role of host country corruption on the quality of investment. High level of corruption may lead to not only lower level but also poor quality FDI. Again, the quality of investment may suffer in terms of the type of projects (less sophisticated), the level of technology (not the state-of-the-art), the management expertise (low to moderate skilled managers), the origin of FDI (coming mostly from second-tier countries), and so on. Each of these is a fruitful arena for further research on corruption and FDI.

Is there investor's "discount" for host country corruption? Knowing that high levels of corruption or perceptions thereof can create problems for attracting foreign investors one has to question what can such countries do to make themselves more competitive as a host nation. Does the idea of offering some form of "discount" make sense? Would it entice some, if not the majority, of the investors to engage in such "risky" contexts? What are the types of "discounts" that would be appropriate for investors? These are only a few of the many questions one can pose for dealing with corruption in the host country from a policy maker's perspective.

Since reinvested profits represents in many instances a substantial proportion of FDI, the question of corruption affecting investors at the time of entry as opposed to during continuing operations deserves attention. This line of inquiry may have a more long term impact on the investor's decision to commit resources and operate. Finally, spatial distribution of FDI is worth examining. Could it be that corruption is localized in major metropolitan areas? Is it that grand corruption is more localized in urban locations whereas petty is more dispersed? And, does the nature and type of investment combined with the type of corruption significantly impact the spatial distribution of FDI? 
Armed with more indices of perceived corruption and governance, we are today better equipped to uncover some more specific relationships. Namely, the burden of corruption appears to vary depending on the type of dealings (taxation, operations permits, judiciary, customs, banking) and the corresponding nuisance. It will be very helpful to learn the relative bearing each of them separately has upon FDI. Next, there are already indications that the firms' size is not without significance in determining the impact corruption exerts upon their FDI. Whether larger companies/projects represent more lucrative prey and the smaller/weaker firms a more vulnerable target needs to be tested. In a similar spirit, one is tempted to examine whether particular industries (say, specialized in the infrastructure development) are more subject to international corruption than others.

In conclusion, while in the past a lot of work has been done in a fairly short period of time more needs to be done. It is only by pursuing the unanswered research questions that the researchers and policy makers can develop an in-depth understanding of corruption as well as possible modes for tackling it.

\section{AUTHOR INFORMATION}

Mohsin Habib is Associate Professor of Management at the University of Massachusetts - Boston. He received his Ph.D. in Management at the University of North Carolina, Chapel Hill. His research explores the relationship between corruption, foreign direct investment (FDI), and multinational corporations (MNC). The MNC's interaction with the developing countries and the different roles (including social responsibility and sustainable development) it plays constitute the primary research agenda. He has published in several journals including the Strategic Management Journal, Journal of International Business Studies, and the International Business Review.

\section{REFERENCES}

1. Ades, A. and Rafael Di Tella. (1996), The Causes and Consequences of Corruption: A Review of Recent Empirical Contributions. IDS Bulletin 27 (2).

2. Aizenman, J. and Spiegel, M.M. (2006), Institutional Efficiency, Monitoring Costs and the Investment Share of FDI, Review of International Economics, 4:683-697.

3. Asiedu, E. (2006), Foreign Direct Investment in Africa: The Role of Natural Resources, Market Size, Government Policy, Institutions and Political Instability, World Economy, 29: 63-77.

4. Beaulieu, E., S. Chen and E. Pohjola (2005), The Determinants of Canadian Direct Investment Abroad, in J. M. Curtis and D. Ciuriak (eds.), Trade Policy Research 2005, Ottawa, Canada, 107-148.

5. Bray, J. (2005), The Use of Intermediaries and Other "Alternatives" to Bribery, in: J. Lambsdorff, M. Taube and M. Schramm (eds.), Corruption and the New Institutional Economics, London: Routledge, 112-137.

6. Business International. (1984), Introduction to the Country Assessment Service. New York: Business International Corporation.

7. Busse, L., Ishikawa, N., Mitra, M., Primmer, D., Surjadinata, K., \& Yaveroglu, T. (1996). The perception of corruption: A market discipline approach, Working Paper, Atlanta, Emory University.

8. Campos, J., D. Lien and S. Pradhan (1999). The Impact of Corruption on Investment: Predictability Matters, World Development, 27 (6): 1059-67.

9. Caetano, J.M.M. and A Caleiro (2005), Corruption and Foreign Direct Investment, What kind of relationship is there? Economics Working Papers, University of Évora, Department of Economics

10. Cuervo-Cazurra, A. (2006), Who Cares About Corruption? Journal of International Business Studies, 37: 807-822.

11. Cuervo-Cazurra, A. (2008), Better the devil you don't know: Types of corruption and FDI in transition economies, Journal of International Management, 14: 12-27.

12. Della Porta, D. and A.Vanucci (1999), Corrupt Exchanges, Actors, Resources and Mechanisms of Political Corruption, New York, NY.

13. Djankov, S., R. La Porta, F. Lopez-de-Silanes and A Shleifer (2002), The Regulation of Entry, Quarterly Journal of Economics, 67: 1-37.

14. Gani, A. (2007), Governance and foreign direct investment links: evidence from panel data estimations, Applied Economic Letters, 14: 753-756.

15. Habib, M. and L. Zurawicki (2001), Country-Level Investments and the Effect of Corruption: Some Empirical Evidence, International Business Review, 10: 687-700. 
16. Habib, M. and L. Zurawicki (2002), Corruption and Foreign Direct Investment, Journal of International Business Studies (JIBS), 33: 291-308.

17. Habib, M. and L. Zurawicki (2005), Corruption and Its Effect on Trade and FDI, in: Global Corruption Report 2005, Berlin: Transparency International, 305-307.

18. Hakkala, K., P-J. Norbäck, and H. Svaleryd (2008), Asymmetric Effects of Corruption on FDI: Evidence from Swedish Multinational Firms, The Review of Economics and Statistics (forthcoming).

19. Hines, J. (1995). Forbidden payment: Foreign bribery and American business after 1977. National Bureau of Economic Research (NBER) Working Paper 5266.

20. Huang, Y. (2005), Are Foreign Firms Privileged By Their Host Governments? Evidence from The 2000 World Business Environment Survey, MIT Sloan Working Paper No. 4538-05.

21. Kotov, D. (2008), How Changing Investment Climate Impacts on the Foreign Investors Investment Decision: Evidence from FDI in Germany, Paper 8777, Munich Personal Research Papers in Economics.

22. Lambsdorff, J. (1998), An empirical investigation of bribery in international trade, European Journal of Development Research, 11 (1): 40-59.

23. Lambsdorff, J. (2003), "How Corruption Affects Persistent Capital Flows", Economics of Governance, 4(3), pp. 229-244.

24. Lambsdorff, J. and U. Teksoz (2005), Between Two Evils - Investors Prefer Grand Corruption! Discussion Paper of the Economics Department, Passau University, V-31.05.

25. Rodriguez, P., Uhlenbruck, K., Eden, L., 2005. Government corruption and the entry strategies of multinationals. Academy of Management Review, 30: 383-396.

26. Rose-Ackerman, S. (1999), Corruption and Government: Causes, Consequences, and Reform, Cambridge, UK.

27. Sanyal, R. and S. Samanta (2008), Effect of Perception of Corruption On Outward US Foreign Direct Investment, Global Business and Economics Review, 10: 123-140.

28. Straub, S. (2008), Opportunism, corruption and the multinational firm's mode of entry, Journal of International Economics, 74:245-263.

29. Uhlenbruck,K., P. Rodriguez, J. Doh, and L. Eden (2006), The Impact of Corruption on Entry Strategy: Evidence from Telecommunication Projects in Emerging Economies, Organization Science, 17: 402-414.

30. Wei, S-J. (1997a), How Taxing is Corruption on International Investors, No. 6030, NBER Working Papers.

31. Wei, S-J. (1997b), Why is Corruption So Much More Taxing Than Tax? Arbitrariness Kills, No 6255, NBER Working Papers.

32. Wei, S-J. and B. Smarzynska (2000), Corruption and Composition of Foreign Direct Investment: FirmLevel Evidence, NBER Working Paper 7969.

33. Winner, H. and P. E.Egger (2006), How Corruption Influences Foreign Direct Investment: A Panel Data Study, Economic Development and Cultural Change, 54: 459-486.

34. Zhao, J.H., S.H. Kim, S.H., and J. Du (2003), The Impact of Corruption and Transparency on Foreign Direct Investment: An Empirical Analysis, Management International Review, 43: 41-62. 
NOTES 